Pendas: Primary Education Journal

Volume 2 Nomor 2, Juli-Desember 2021

P-ISSN: 2686-5130 || E-ISSN : 2776-298X

Availabel online at: http://journal.unram.ac.id/index.php/pendas/index

\title{
ANALISIS PENANAMAN NILAI KARAKTER PADA MATA PELAJARAN PENDIDIKAN JASMANI DI SD NEGERI GUGUS 8 KECAMATAN PRAYA BARAT
}

\author{
Ali Aksa Rahman ${ }^{1 *}$, Safruddinn $^{2)}$, Husniati $^{3)}$ \\ 1),2),3) Prodi PGSD, FKIP - Universitas Mataram \\ *Corresponding Author: aanpengempok@gmail.com
}

\begin{tabular}{l}
\hline ARTICLE INFO \\
\hline Article history \\
Received : October $12^{\text {st }}, 2021$ \\
Revised : November $19^{\text {st }}, 2021$ \\
Accepted : Desember $12^{\text {st }}, 2021$
\end{tabular}

Keywords:

Cultivating character values, physical education, inhibiting factors, supporting factors

\section{ABSTRACT}

This study aims to describe how to instill character values in physical education subjects at SD Negeri Gugus 8, Praya Barat District. The problems studied in this study are (1) what are the ways or steps in inculcating character values in physical education subjects in elementary schools, (2) what are the things that affect the inculcation of character values in physical education subjects. The type of research used is descriptive qualitative research with data collection techniques using interviews and documentation studies. While the data analysis technique used is the Miles and Huberman model which consists of stages (1) data reduction (2) data presentation (3) data verification, and using triangulation methods as data validity. Based on the results of data analysis, the results of the study indicate that, (1) there are several ways or steps that can be taken in instilling character values in physical education subjects, namely: (a) teachers improve their attitudes first (b) familiarize students with praying before and after learning; (c) familiarize students with rows; (d) maximizing each set of learning practices; (e) modification of game rules on learning materials; (f) reaffirming the character values contained in the learning materials at the learning reflection stage; (g) coordinate with parents and guardians of students. (2) things that affect the inculcation of character values in physical education subjects consist of: (a) inhibiting factors which include certain cultural traditions in society, limitations of tools and media, and student delinquency; (b) supporting factors, which include teachers, student readiness, learning methods and techniques, as well as the involvement of various parties.

ABSTRAK Penelitian ini bertujuan untuk mendeskripsikan cara penanaman nilai karakter pada mata pelajaran pendidikan jasmani di SD Negeri Gugus 8 Kecamatan Praya Barat. Adapun permasalahan yang dikaji dalam penelitian ini adalah (1) bagaimanakah cara atau langkah dalam penanaman nilai karakter pada mata pelajaran pendidikan jasmani di sekolah dasar, (2) apa saja hal-hal yang memengaruhi penanaman nilai karakter pada mata pelajaran pendidikan jasmani. Jenis penelitian yang digunakan adalah penelitian kualitatif deskriptif dengan teknik pengumpulan data menggunakan wawancara dan studi dokumentasi. Sedangkan teknik analisis data yang digunakan adalah model Miles dan Huberman yang terdiri dari tahap (1) reduksi data (2) penyajian data (3) verifikasi data, dan menggunakan triangulasi metode sebagai validitas data. Berdasarkan hasil analisis data, hasil penelitian menunjukkan bahwa, (1) terdapat beberapa cara atau langkah yang dapat dilakukan dalam menanamkan 
nilai karakter pada mata pelajaran pendidikan jasmani yaitu: (a) guru memperbaiki sikapnya terlebih dahulu (b) membiasakan peserta didik berdo'a sebelum dan sesudah pembelajaran; (c) membiasakan peserta didik baris-berbaris; (d) memaksimalkan setiap rangkaian praktik pembelajaran; (e) modifikasi peraturan permainan pada materi pembelajaran; (f) mempertegas kembali nilai karakter yang terkandung dalam materi pembelajaran pada tahap refleksi pembelajaran; (g) berkoordinasi dengan orang tua wali murid. (2) hal yang memengaruhi penanaman nilai karakter pada mata pelajaran pendidikan jasmani terdiri atas: (a) faktor penghambat yaitu meliputi tradisi budaya tertentu dalam masyarakat, keterbatasan alat dan media, dan kenakalan peserta didik; (b) faktor pendukung yaitu meliputi guru, kesiapan peserta didik, metode dan teknik pembelajaran, serta keterlibatan berbagai pihak.

\section{A. PENDAHULUAN}

Karakter merupakan sesuatu yang ada pada diri setiap individu sebagai acuan dan arah untuk berperilaku dalam kehidupan sehari-hari, hal ini sejalan dengan yang dinyatakan oleh Rosidatun (2018: 19) yakni, karakter dimaknai sebagai cara berpikir dan cara beperilaku untuk menjalani hidup ataupun bekerja sama. Selanjutnya Koesoema (dalam Sukiyat 2020: 3) menyatakan bahwa karakter secara etimologi berasal dari bahasa Yunani "karasso" yang artinya "cetak biru" atau "format dasar". Sehingga dapat dikatakan bahwa karakter sudah melekat pada diri setiap manusia semenjak dia dilahirkan, namun selanjutnya karakter tersebut akan dibentuk oleh lingkungan tempat tinggal setiap individu.

Dalam kehidupan bernegara karakter memiliki peranan yang fundamental. Suatu negara tidak cukup baik bila hanya mengandalkan pengetahuan intelektual penduduknya saja, melainkan suatu negara juga perlu memberikan perhatian yang ekstra terhadap karakter penduduknya. Sebab jika intelektual tidak diimbangi dengan karakter maka akan menimbulkan masalah yang serius, contoh populernya yaitu kasus korupsi. Kasus korupsi memberikan gambaran bahwa orang pintar bisa saja merugikan banyak pihak jika ia tidak berkarakter.

Pada uraian sebelumnya dapat dipahami bahwa karakter dapat berubah dan terbentuk oleh lingkungan. Hal ini mengindikasikan bahwa karakter dapat diubah dan diperbaiki dengan cara tertentu. Hal ini menunjukkan kemurahan hati Sang Pencipta, karena jika karakter tidak dapat diubah maka makna kebebasan yang kita miliki akan siasia. Hal ini selaras dengan yang dinyatakan oleh Koesoema (dalam Sukiyat, 2020: 4) "struktur antropologis kodrati kita mengatakan bahwa kita bisa mengubahnya. Jika tidak, konsep kebebasan yang kita miliki tidak bermakna dan halusinasif'.

Oleh karena itu terdapat salah satu cara yang dapat dilakukan untuk mengubah, dan mengembangkan karakter, yaitu dengan menjalankan pendidikan karakter. Pendidikan karakter memang sepatutnya dilaksanakan terutama bagi generasi anak-anak sekolah dasar yang belum bisa menyikapi perubahan di era globalisasi ini. Sehingga dalam rangka menyikapi betapa pentingnya karakter dalam kehidupan berbangsa dan bernegara, Pemerintah Negara Kesatuan Republik Indonesia memberlakukan Kurikulum 2013 yang berbasis pendidikan karakter. 
Pendidikan karakter yang termuat dalam kurikulum 2013 merupakan upaya untuk mengimbangi maraknya proses globalisasi. Sebagaimana kita tahu bahwa globalisasi telah menjangkau setiap kalangan, salah satunya anak usia sekolah dasar. Globalisasi juga telah memberikan dampak yang signifikan terhadap kehidupan masyarakat, ada dampak positif dan ada pula dampak negatifnya. Adapun yang menjadi masalah tentu dampak negatif itu sendiri, dan dari setiap kalangan yang terdampak globalisasi, yang paling rentan terkena dampak tersebut adalah anak-anak.

Pengaruh buruk globalisasi terhadap anak bahkan bisa terlihat di lokasi yang masuk dalam kategori terpencil, yakni di SDN Tomang Omang Desa Selong Belanak yang merupakan salah satu SD dalam lingkup Gugus 8 Kecamatan Praya Barat Kabupaten Lombok Tengah. Setelah dilakukan wawancara dengan salah satu guru yang mengabdi di sekolah tersebut didapatkan informasi bahwa, peserta didik masih kerap tidak disiplin menggunakan sepatu, kerap menjahili temannya, terkadang mengikuti kata-kata kasar yang didengarnya dari vlog you tube, tik tok, dan lain sebagainya serta berbagai bentuk kenakalan lainnya.

Keadaan tersebut tentu tidak boleh dibiarkan begitu saja karena menyangkut masa depan bangsa dan negara. Diperlukan langkah penyelesaian dan pencegahan, langkah tersebut tentu dengan memaksimalkan daya dan upaya dalam menjalankan pendidikan karakter yang tertuang dalam kurikulum 2013, salah satunya melalui mata pelajaran pendidikan jasmani.

Pendidikan jasmani dipilih sebagai objek penelitian atau topik dalam penelitian ini sebagai bentuk pemanfaatan segala daya dan upaya dalam memaksimalkan pelaksanaan pendidikan karakter itu sendiri. Artinya penelitian ini secara tidak langsung mengajak untuk tidak hanya mengandalkan mata pelajaran-mata pelajaran yang memang secara material mengajarkan nilai karakter kepada peserta didik, seperti mata pelajaran pendidikan agama, kewarganegaraan, IPS, dan lain sebagainya. Melainkan penelitian ini berupaya menunjukkan bahwa mata pelajaran pendidikan jasmani juga perlu dimaksimalkan dalam penanaman nilai karakter kepada peserta didik. Selain itu pembelajaran pendidikan jasmani dinilai memiliki potensi penanaman nilai karakter yang kompleks. Karena dalam pembelajaran pendidikan jasmani, peserta didik berinteraksi dengan gurunya, teman-temanya, dan lingkungannya secara lebih intens dibandingkan saat dalam pembelajaran mata pelajaran lainnya.

Oleh karena itu, akan dilaksanakan penelitian yang berjudul Penanaman Nilai Karakter Melalui Mata Pelajaran Pendidikan Jasmani di SD Gugus 8 Kecamatan Praya Barat Kabupaten Lombok Tengah. Dalam Gugus 8 Kecamatan Praya Barat terdapat 5 sekolah dasar, namun dalam penelitian ini akan dipilih 3 sekolah sebagai partisipan, yakni SDN Tomang Omang, SDN Selong Belanak, dan SDN Tongker. Penelitian ini bertujuan untuk mengetahui bagaimana cara penanaman nilai karakter di sekolah dasar, dan hal-hal yang memengaruhi penanaman nilai karakter pada mata pelajaran pendidikan jasmani.

\section{B. METODE PENELITIAN}

Jenis pendekatan penelitian yang akan dilakukan adalah penelitian kualitatif deskriptif. Anggito dan Setiawan (2018: 9) mengemukakan bahwa "penelitian kualitatif tidak menggunakan statistik, tetapi melalui pengumpulan data, analisis, kemudian 
diinterpretasikan”. Untuk itu penelitian ini bertujuan untuk mendeksripsikan tentang topik permasalahan sesuai dengan kaidah atau ketentuan penelitian kualitatif itu sendiri. Penelitian ini dilaksanakan di SD yang termasuk dalam lingkup Gugus 8 Kecamatan Praya Barat Kabupaten Lombok Tengah, yang nantinya akan dipilih tiga SD sebagai partisipan yakni SDN Tomang Omang, SDN Selong Belanak, dan SDN Tongker. Lokasi ini dipilih dengan mempertimbangkan beberapa kriteria, yaitu berkaitan dengan masalah kenakalan sebagai dampak globalisasi, dan guru pendidikan jasmani yang sudah berpredikan sebagai PNS.

Sumber data dalam penelitian ini yaitu informan dan dokumen-dokumen, di mana informan dalam penelitan ini yaitu guru pendidikan jasmani. Data yang dikumpulkan berupa data primer dan sekunder, data primer didapatkan dari informasi yang diberikan oleh informan saat proses wawancara, dan data sekunder didapatkan dari proses telaah dokumen atau studi dokumentasi. Adapun data yang dikumpulkan merujuk pada topik penelitian, yaitu mengenai penanaman nilai karakter pada mata pelajaran pendidikan jasmani. Lalu berdasarkan definisi operasional penelitian ini, nilai-nilai karakter yang akan ditelaah adalah nilai karakter religius, jujur, disiplin, mandiri, peduli lingkungan, peduli sosial, dan tanggung jawab.

Teknik pengumpulan data yang digunakan adalah teknik wawancara dan teknik studi dokumentasi. Wawancara merupakan proses tanya jawab yang dilakukan oleh dua orang atau lebih dengan tujuan tertentu, di mana salah satu pihak sebagai pewawancara "interviewer" dan yang lainnya sebagai "interviewee" atau yang diwawanarai (Hardani, dkk, 2020: 137). Jenis wawancara yang digunakan dalam penelitian ini adalah wawancara terpimpin. Adapun teknik studi dokumentasi adalah cara mengumpulkan data dengan mencatat data-data yang sudah ada (Hardani, dkk, 2020: 149). Dokumen yang diteliti adalah dokumen yang berkaitan dengan informan dan keterangan dari informan, dalam hal ini berupa RPP dan dokumen-dokumen yang diterbitkan oleh lembaga pemerintah atau surat kabar. Dalam melakukan pengumpulan data tersebut peneliti berperan sebagai instrumen utama dan terdapat pula instrument pendukung berupa pedoman wawancara dan tabel kerja studi dokumentasi.

Teknik analisis data yang digunakan adalah model Miles dan Huberman yang terdiri dari tiga tahap yaitu reduksi data, penyajian data, dan penarikan simpulan atau verifikasi. Patilima (dalam Hardani, dkk, 2020: 164) menyatakan Reduksi data adalah proses pemilihan, pemusatan perhatian pada penyederhanaan, pengabstrakan, dan transformasi data yang muncul dari catatan-catatan lapangan. Selanjutnya Hardani, dkk (2020: 167) menyatakan bahwa "Penyajian yang dimaksud Miles dan Huberman, sekumpulan informasi tersusun yang memberi kemungkinan adanya penarikan simpulan dan pengambilan tindakan”. Dan penarikan simpulan adalah tahap menentukan inti sari data temuan penelitian yang menunjukkan jawaban atas pertanyaan penelitian. Sementari itu dalam hal validitas data digunakan triangulasi metode, yakni menggunakan lebih dari satu metode pengumpulan data pada satu objek penelitian, dalam hal ini digunakan teknik wawancara dan teknik telaah dokumen. 


\section{HASIL DAN PEMBAHASAN}

Tujuan penelitian yaitu untuk mengetahui deskripsi cara penanaman nilai karakter pada mata pelajaran pendidikan jasmani di sekolah dasar, dan untuk mengetahui hal-hal yang memengaruhi penanaman nilai karakter pada mata pelajaran pendidikan jasmani di sekolah dasar. Untuk itu data yang didapat dari hasil wawancara yang dilakukan terhadap guru pendidikan jasmani SDN Selong Belanak, SDN Tongker, dan SDN Tomang Omang, akan dipaparkan mengacu pada tujuan tersebut, pemaparannya sebagai berikut:

\section{Cara Penanaman Nilai Karakter pada Mata Pelajaran Pendidikan Jasmani di Sekolah} Dasar

Pertama, guru memperbaiki sikapnya terlebih dahulu. Hal ini perlu dilakukan dalam rangka memenuhi peran guru sebagai model atau teladan. Informasi ini didapat atas pernyataan guru pendidikan jasmani SDN Selong Belanak yang mengatakan: "Dan sebenarnya kita sebagai guru terlebih dahulu yang memberikan contoh, itulah yang dinilai oleh anak."

Juhji dalam Indrawan, dkk (2020: 93) menyatakan bahwa salah satu peran guru dalam pembelajaran adalah guru sebagai teladan atau model. Karena itu guru musti berupaya memperbaiki karakter dirinya sendiri terlebih dahulu agar bisa menjadi teladan dan contoh yang baik, sehingga diharapkan mampu memperbaiki atau mengubah karakter peserta didik. Misalnya ketika guru ingin menanamkan nilai karakter disiplin kepada peserta didik, maka dialah sosok yang paling awal harus bersikap disiplin.

Kedua, mengajak peserta didik untuk berdo'a sebelum dan sesudah melakukan pembelajaran. Langkah ini perlu dilakukan dalam menanamkan nilai relgius kepada peserta didik. Informasi ini didapat atas pernyataan yang dikemukakan oleh tiga informan yang diwawancarai, di mana mereka mengatakan hal yang kurang lebih sama yaitu: "Untuk karakter religius itu sudah terbiasa setiap kita ingin memulai pembelajaran kita mengajak siswa untuk berdo'a terlebih dahulu".

Membiasakan peserta didik untuk berdo'a akan memberikan dasar untuk sikap selalu melibatkan Tuhan Yang Maha Esa dalam setiap kegiatan yang dilakukan. Peserta didik juga secara langsung mengamalkan ajaran agamanya, sehingga secara langsung pula amalan itu menjadi pengalaman peserta didik yang nyata, tidak dalam bentuk kata-kata verbal yang mungkin sulit diterka oleh peserta didik.

Ketiga, membiasakan peserta didik baris-berbaris. Hal ini perlu dilakukan dalam mendukung terbentuknya sikap disiplin peserta didik. Informasi ini didapat atas pernyataan yang dikemukakan oleh guru SDN Tongker yaitu: "Sebelum mulai pembelajaran biasanya di SDN Tongker itu berdo'a, sesudah berdo'a kemudian berbaris, yang siswa kecil di depan dan yang besar di belakang”.

Baris-berbaris merupakan kagiatan yang bisa dikatakan tidak terlepaskan dari kegiatan pembelajaran pendidikan jasmani. Kegiatan baris-berbaris ini penting untuk menanamkan nilai karakter disiplin kepada peserta didik.

Keempat, memaksimalkan setiap rangkaian pembelajaran. Setiap materi pembelajaran pendidikan jasmani pada dasarnya memiliki nilai karakter tersendiri di dalamnya, untuk itu kegiatan pembelajaran perlu dimaksimalkan. Informasi ini didapat berdasarkan apa yang dikatakan oleh guru pendidikan jasmani SDN Selong Belanak yaitu: 
"Untuk sikap atau karakter-karakter yang lainnya itu tidak serta-merta semuanya tergabung dalam satu materi, dalam satu materi itu ada karakter-karakter khusus yang ditonjolkan."

Sesuai dengan data yang ditemukan dalam proses penelitian, untuk nilai karakter jujur, disiplin, mandiri, peduli lingkungan, peduli sosial, dan tanggung jawab pada dasarnya secara tersirat telah terkandung dalam materi-materi tertentu dalam pembelajaran pendidikan jasmani. Untuk itu memaksimalkan setiap rangkaian praktik materi pembelajaran perlu dilakukan.

Kelima, memodifikasi peraturan permainan dalam pembelajaran. Hal ini dilakukan dalam rangka mengantisipasi keterlenaan peserta didik dalam permainan materi pembelajaran pendidikan jasmani. Informasi ini didapat berdasarkan apa yang dikatakan oleh informan, di mana tiga informan tersebut kompak mengatakan: "Saya terkadang memodifikasi aturan itu, agar tidak terlalu berlarut-larut mereka hanya memikirkan kemenangan atau hanya memikirkan diri mereka sendiri." Modifikasi peraturan permainan dalam materi pembelajaran perlu dilakukan untuk menyesuaikan kemampuan peserta didik, dan juga untuk mencegah peserta didik berlarut-larut dalam kesenangan permainan.

Keenam, mempertegas kembali nilai karakter yang terkandung dalam materi pada tahap refleksi pembelajaran. Langkah ini perlu dilakukan untuk memeberikan gambaran kepada peserta didik tentang nilai karakter yang secara tersirat terkandung dalam materi pembelajaran. Informasi ini didapat berdasarkan apa yang dikatakan oleh guru SDN Selong Belanak yaitu: "Dan di kegiatan refleksi pembelajaran itu kita pertegas kembali mengenai nilai karakter itu."

Kegitan refleksi adalah kegiatan yang dilakukan setelah kegiatan inti dengan tujuan untuk menyampaikan hal apa yang telah dilakukan dan menyampaikan hasil pengamatan (Aprilya, 2020: 18). Dalam proses pembelajaran, kegiatan refleksi dilakukan setelah rangkaian kegiatan inti selesai. Pada tahap refleksi pembelajaran ini guru menyampaikan hal-hal yang perlu ditekankan ataupun yang perlu diperbaiki lagi.

Ketujuh, berkoordinasi dengan orang tua atau wali murid. Hal ini diperlukan untuk mendukung keberlanjutan proses pendidikan karakter, dan juga sebagai langkah yang tepat dalam pembelajaran jarak jauh pada masa pandemi Covid-19. Informasi ini didapat berdasarkan apa yang dinyatakan oleh informan, di mana tiga informan yang bersangkutan mengatakan hal yang kurang lebih sama, yaitu: "Kita diskusi bersama orang tua, karena memang di sini peran keluarga sangat penting sebab waktu siswa banyak atau bahkan seluruh waktu siswa itu ada di rumah."

Seperti yang diketahui bersama bahwa peserta didik menghabiskan sebagian besar waktunya di rumah bersama keluarga, terlebih jika mengingat kondisi pandemi Covid-19 yang masih belum selesai. Untuk itu penting bagi peserta didik juga menerima pendidikan karakter dari keluarga. Sebab jika hanya mengandalkan pembelajaran dari sekolah itu tidak cukup, percuma saja peserta didik diajarkan dan dilatih disiplin di sekolah, sedangkan di rumah mereka tidak mendapatkan kondisi yang ideal untuk menerapkan kedisiplinan (Luthviyani et al, 2019). 
Hal-hal yang Memengaruhi Penanaman Nilai Karakter pada Mata Pelajaran Pendidikan Jasmani di Sekolah Dasar.

Faktor Penghambat yaitu berdasarkan wawancara yang dilakukan dapat diketahui bahwa hal-hal yang menghambat penanaman nilai karakter pada mata pelajaran pendidikan jasmani yaitu, budaya-budaya tertentu dalam masyarakat, keterbatasan alat dan media pembelajaran, serta kenakalan peserta didik. Informasi ini didapatkan berdasarkan apa yang dinyatakan oleh guru SDN Selong Belanak, yaitu: "menurut pengalaman saya nanti kan kadang alat dan bahan yang membuat kita terhambat, memang ada kita punya alat tapi jumlahnya tidak memadai." Dan juga guru pendidikan jasmani SDN Tomang Omang mengatakan: "kalau itu biasanya ada anak yang biasanya kalau dia nakal itu diikuti oleh anak yang lain, dan pembelajaran jadi tidak kondusif."

Pertama, tradisi Budaya Tertentu dalam Masyarakat. Terdapat perayaan budaya tertentu yang menuntut waktu dan energi yang tidak sedikit, lalu perayaan itu diikuti oleh anak-anak, hal tersebut tentu akan menyebabkan anak tidak bugar dan kurang fit saat dalam pembelajaran, khususnya pembelajaran pendidikan jasmani.

Kedua, Keterbatasan Alat dan Media. Alat dan media pembelajaran dapat membantu peserta didik untuk memahami pembelajaran dengan lebih baik. Untuk itu jika alat dan media pembelajaran terbatas atau tidak mencukupi, maka akan menghambat peserta didik dalam memahami materi pembelajaran, dan berimbas pada pemahaman peserta didik tentang nilai karakter yang terkandung dalam materi.

Ketiga, Kenakalan Peserta Didik. Hal ini tentu menghambat terciptanya kondisi pembelajaran yang baik dalam upaya menanamkan nilai karakter, khususnya melalui mata pelajaran pendidikan jasmani.

Selanjutnya untuk studi dokumentasi dilakukan untuk membuktikan kevalidan informasi yang diberikan oleh informan. Adapun informasi yang didapat dalam studi dokumentasi tersebut dipaparkan berdasarkan jenis dokumen sebagai berikut: (1) RPP; (2) Kalender Pendidikan; (3) Data Statistik Wilayah.

Dari RPP ini didapati informasi bahwa proses pembelajaran yang dilakukan sesuai dengan yang dikemukakan dalam wawancara, sehingga informasi dinyatakan valid.

Dalam kalender pendidikan yang ditelaah adalah tentang hari libur untuk tradisi budaya yang tidak sesuai, di mana hal ini dapat menghambat penanaman nilai karakter. Di mana ditemukan bahwa memang benar hari libur yang ditetapkan tidak sesuai dengan hari tradisi dilakukan.

Hal yang ditelaah dalam data statistik wilayah ini adalah tentang latar belakang sekolah atau profil wilayah sekolah. Di mana salah satu informasi yang ditemukan yaitu jarak dari wilayah sekolah ke Ibu Kota Kabupaten terbilang jauh dan sulit dijangkau, hal ini menyebabkan kurangnya suplai media dan alat pembelajaran.

Faktor pendukung penanaman nilai karakter pada mata pelajaran pendidikan jasmani yang didapat dari hasil wawancara yaitu, guru, kesiapan peserta didik, dan metode pembelajaran. informasi ini didapatkan berdasarkan apa yang disampaikan oleh guru pendidikan jasmani SDN Selong Belanak, yaitu: "Kalau yang paling mendukung yaitu siswa, terus saya sendiri sebagai gurunya, terus cara penyampaiannya itu yang mendukung." 
Faktor pendukung pertama yaitu guru. Dalam mata pelajaran pendidikan jasmani, keberhasilan pembelajaran khususnya dalam penanaman nilai karakter tidak terlepas dari kemampuan guru menjalankan perannya. Dalam mata pelajaran pendidikan jasmani terdapat materi-materi pembelajaran yang bersifat praktik di lapangan, sehingga peran guru sangat dibutuhkan untuk mendukung kepahaman peserta didik.

Faktor pendukung kedua yaitu kesiapan Peserta Didik. Faktor kesiapan peserta didik juga mendukung terciptanya pembelajaran yang baik untuk menanamkan nilai karakter melalui mata pelajaran pendidikan jasmani. Kesiapan peserta didik dalam menerima pembelajaran selain ditentukan oleh kemampuan guru dalam kegiatan apersepsi pembelajaran, juga ditentukan oleh kesehatan dan keadaan tubuh peserta didik (Khairani et al, 2021).

Faktor pendukung ketiga yaitu metode dan Teknik Pembelajaran. Metode dan teknik pembelajaran sangat perlu dpertimbangkan oleh guru dalam melaksanakan kegiatan pembelajaran. Karena metode dan teknik pembelajaran yang baik akan mendukung terciptanya suasana pembelajaran yang baik pula bagi peserta didik.

\section{PENUTUP}

\section{Simpulan}

Berdasarkan data yang ditemukan dan telah dianalisis dalam proses penelitian, dapat ditarik kesimpulan sebagai berikut:

Cara Penanaman Nilai Karakter pada Mata Pelajaran Pendidikan Jasmani di Sekolah Dasar yaitu (1) guru memperbaiki sikapnya terlebih dahulu; (2) mengajak peserta didik untuk berdo'a sebelum dan sesudah melakukan pembelajaran; (3) membiasakan peserta didik baris-berbaris; (4) memaksimalkan setiap rangkaian pembelajaran; (5) memodifikasi peraturan permainan dalam pembelajaran; (6) mempertegas kembali nilai karakter yang terkandung dalam materi pada tahap refleksi pembelajaran; dan (7) berkoordinasi dengan orang tua atau wali murid.

Hal-hal yang Memengaruhi Penanaman Nilai Karakter pada Mata Pelajaran Pendidikan Jasmani di Sekolah Dasar. Adapun faktor Penghambat yaitu : (1) tradisi Budaya Tertentu dalam Masyarakat; (2) Keterbatasan Alat dan Media; (3) Kenakalan Peserta Didik.

Adapun Faktor Pendukung yang ditemukan yaitu: (1) Guru; (2) Kesiapan Peserta Didik; (3) Metode dan Teknik Pembelajaran.

\section{Saran}

Pendidikan karakter merupakan langkah terbaik dalam membentuk generasi penerus bangsa yang baik dan mampu memegang amanah cita-cita bangsa, pendidikan karakter juga penting dalam mengimbangi proses glonalisasi yang bisa menyebabkan pergeseran moral. Oleh karena itu disarankan agar pendidikan karakter ini untuk dimaksimalkan, salah satunya melalui mata pelajaran pendidikan jasmani. Secara lebih khusus saran untuk beberapa pihak terkait topik dan temuan-temuan dalam penelitian ini adalah sebagai berikut: 
Bagi sekolah dan guru khususnya guru mata pelajaran pendidikan jasmani, disarankan untuk mempertimbangkan cara atau langkah dalam menanamkan nilai karakter melalui mata pelajaran pendidikan jasmani sesuai dengan yang telah dikaji, dan mengenai hal-hal yang dapat menghambat dan mendukung penanaman nilai karakter tersebut. Mengingat peran guru sangat kompleks dalam pembelajaran.

Bagi masyarakat dan orang tua wali murid, disarankan untuk mendukung keberlanjutan usaha penanaman nilai karakter melalui mata pelajaran pendidikan jasmani. Mengingat situasi pandemi yang bisa menyebabkan pembelajaran dilangsungkan dari rumah, jadi masyarakat dan orang tua musti menciptakan kondisi yang ideal untuk pembentukan karakter pseserta didik.

Bagi peneliti selanjutnya, disarankan untuk mengembangkan topik dalam penelitian ini, mengingat pendidikan karakter begitu penting dalam membentuk generasi bangsa yag baik.

\section{DAFTAR PUSTAKA}

Aprilya, Anggia Prajnaparamita. (2020). Penggunaan Model Inquiry Learning dalam Pembelajaran. Malang: Ahlimedia Press.

Hardani dkk. (2020). Metode Penelitian Kualitatif \& Kuantitatif. Jawa Timur: CV Pustaka Ilmu.

Indrawan, Irjus dkk. (2020). Guru Sebagai Agen Perubahan. Klaten: Penerbit Lakeisha.

Khairani, D., \& Putra, E. D. (2021). Analisis Implementasi Lima Nilai Karakter Pendidikan pada Kegiatan Pembelajaran di Sekolah Dasar. Jurnal Basicedu, 5(4), 2247-2255.

Luthviyani, I. R., Setianingsih, E. S., \& Handayani, D. E. (2019). Analisis Pelaksanaan Ekstrakurikuler Pramuka Terhadap Nilai-nilai Karakter Siswa di SD Negeri Pamongan 2. Jurnal PGSD: Jurnal Ilmiah Pendidikan Guru Sekolah Dasar, 12(2), 113-122.

Rosidatun. (2018). Model Implementasi Pendidikan Karakter. Gresik: Caremedia Comunication.

Sukiyat. (2020). Strategi Implementasi Pendidikan Karakter. Surabaya: CV Jakad Media Publishing. 